\title{
Summary of the evolution of the fortifications of Santa Barbara Castle in Alicante from its origins to the beginning of the eighteenth century
}

\author{
M. I. Pérez Millan \& A. B. González Avilés \\ Building Constructions Department, University of Alicante, Spain
}

\begin{abstract}
Since ancient times, Alicante has been considered a strategic location on the east coast of Spain. Situated close to the sea, it is protected to the southeast by the Cape of Huerta and to the southwest by the Cape of Santa Pola. The city lies at the foot of Mount Benacantil, a high outcrop which has been the site of defensive buildings since time immemorial due to its naturally strong position: it was undoubtedly one of the strongest natural sites in the Levant. Its summit, lying 160 metres above the sea, is topped by a series of fortified enclosures now known as Santa Barbara Castle. This paper briefly describes the alterations made to the castle fortifications from its origins through the Renaissance, including the Muslim and Christian periods until the late fifteenth century and subsequent alterations to adapt new bastioned fortification techniques, and depicts the status of the fortress in each period. This paper is the result of doctoral research carried out at different national and international archives and leading to a thesis presented in 2011.
\end{abstract}

Keywords: military fortification, military engineers, Alicante, architectural heritage, castle, War of the Spanish Succession.

\section{Introduction}

This paper provides a summary of the architectural evolution of Santa Barbara Castle from its Muslim origins until the 18th century. The information presented here is the result of doctoral research $[1,2]$ carried out in more than twenty national and international archives, visits to which were funded in 2010 and 2014 
by the Vice-Chancellor's Office for Research at the University of Alicante, and of collaboration on the research project "Estudio histórico-constructivo y del estado de conservación del Castillo de Santa Bárbara (Alicante) (GV07/150)". This paper has been organised according to the main stages of construction of Santa Barbara Castle, which can be identified as the Muslim era, Christian era, 16 th century, 17 th century and 18 th century.

\section{Architectural evolution of Santa Barbara Castle in Alicante}

The stages in the architectural evolution of Santa Barbara Castle in Alicante are described below.

\subsection{Muslim era}

A study of the Muslim era was based on local documents written by researchers, chroniclers and Arab geographers of the time, which have been studied by other authors [3].

During the Muslim era, growth of the fortified city and castle occurred in four stages (Figure 1):

- First stage: the origins of the city of Alicante, and therefore of the Muslim citadel Hisn Laqant, may lie in the 9th century, a period characterised by peace and prosperity. In the first stage of Muslim rule (late 9th-early 10th centuries), Alicante would have consisted of a rectilinear fortress with square crenellated towers sited on Mount Benacantil, and buildings beside the sea.

- Second stage: in the second stage of Muslim rule, corresponding to the Taifa period (late 10th-early 11th centuries), economic prosperity and associated population growth led to the emergence of a town on the side of Mount Benacantil.

- Third stage: the end of the 11th century witnessed a steady decline in the socioeconomic well-being of the previous stage and a profound political and economic crisis, which gave way to a period of Almoravid rule. Al-Idrisi likened the city to Medina, implying the existence of a fortified enclosure, and also described a citadel that was difficult to enter. It is safe to assume that the middle ward, located between the citadel and the fortified town beyond, was built at this time.

- Fourth stage: during the fourth stage, corresponding to Almohad rule, Alicante once again experienced population growth which was reflected in further construction beyond the walls. Given the growth of the outlying town, there was a need to expand the ward, and what better location than the top of Mount Benacantil, protected from sea-launched attack.

To sum up, the original castle was a rectilinear Muslim citadel with square towers (Figure 1, 1. citadel). Subsequently, the Almoravids built a fortified enclosure around the city, and a ward in the middle (Figure 1, 3. ward). Finally, due to population growth, the Almohads endowed the castle with a new ward, 
adapted to the terrain on the top of Mount Benacantil (Figure 1, 3. ward). Thus, by the beginning of the 13th century, the castle consisted of three separate fortified enclosures: the citadel (the highest part of the fortress, located 160 metres above the sea), the middle ward (150 metres above the sea) and the old ward (between 140 and 120 metres above the sea).

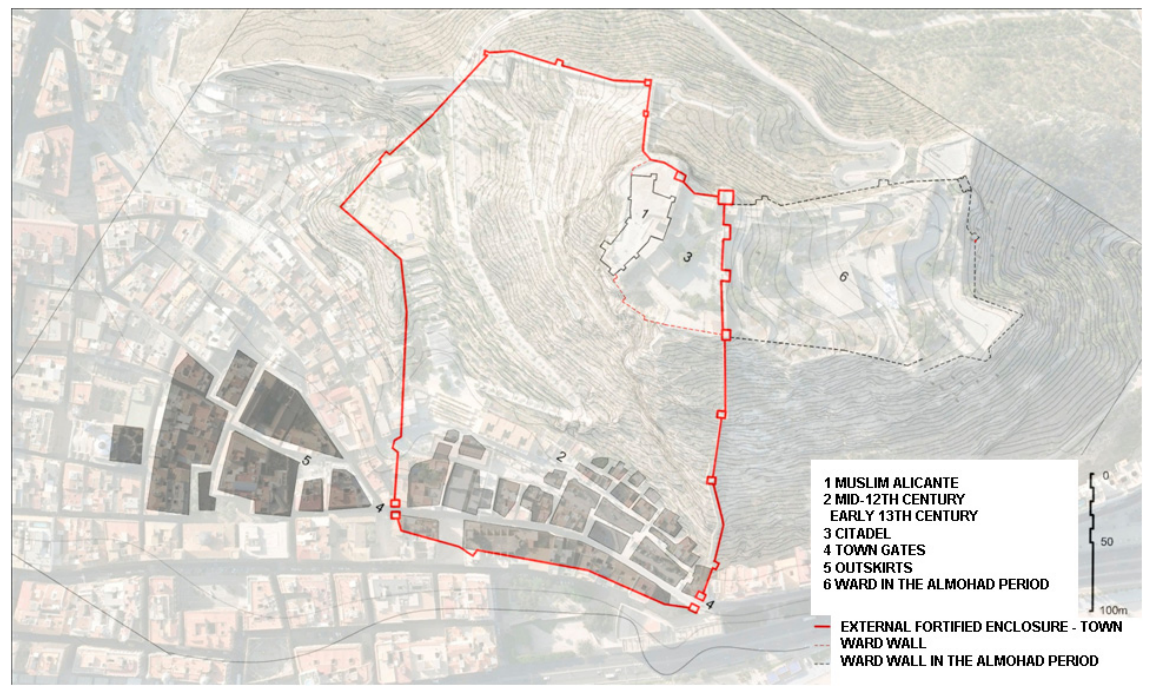

Figure 1: Present-day photograph showing the historical evolution of the castle in the Muslim era (source: authors).

\subsection{Christian era}

In the Christian era, under Castilian and later Aragonese rule, the defensive structure of the castle was barely altered, and the three Muslim enclosures were conserved.

Thorough archival research by José Hinojosa [5] has revealed that the most significant alterations during the Christian era were carried out in the late 15th century. Other research pertinent to the present study includes that by Vicente Martínez (such as his publication of the letter of King Martín I "the Humane", which detailed the garrison necessary in some of the castle towers) [6], the hypotheses of Marius Beviá and Eduardo Camarero [7] regarding the mediaeval citadel and gates, and the results of excavations carried out by Pablo Rosser in the highest esplanade of the castle known as the "Macho del Castillo" [8].

Since the mediaeval towers and all their characteristic elements were razed in the 18th century, our research on this period was mainly focused on an attempt to reconstruct the status of the castle at this time through the study and analysis of documentary sources held in the previously mentioned archives, including drawings by Vespasiano Gonzaga (1575) (Figure 2). This enabled us to locate the names of parts of the fortification in each of the three enclosures, as well as the most important alterations carried out in the late 15 th century (given in the 


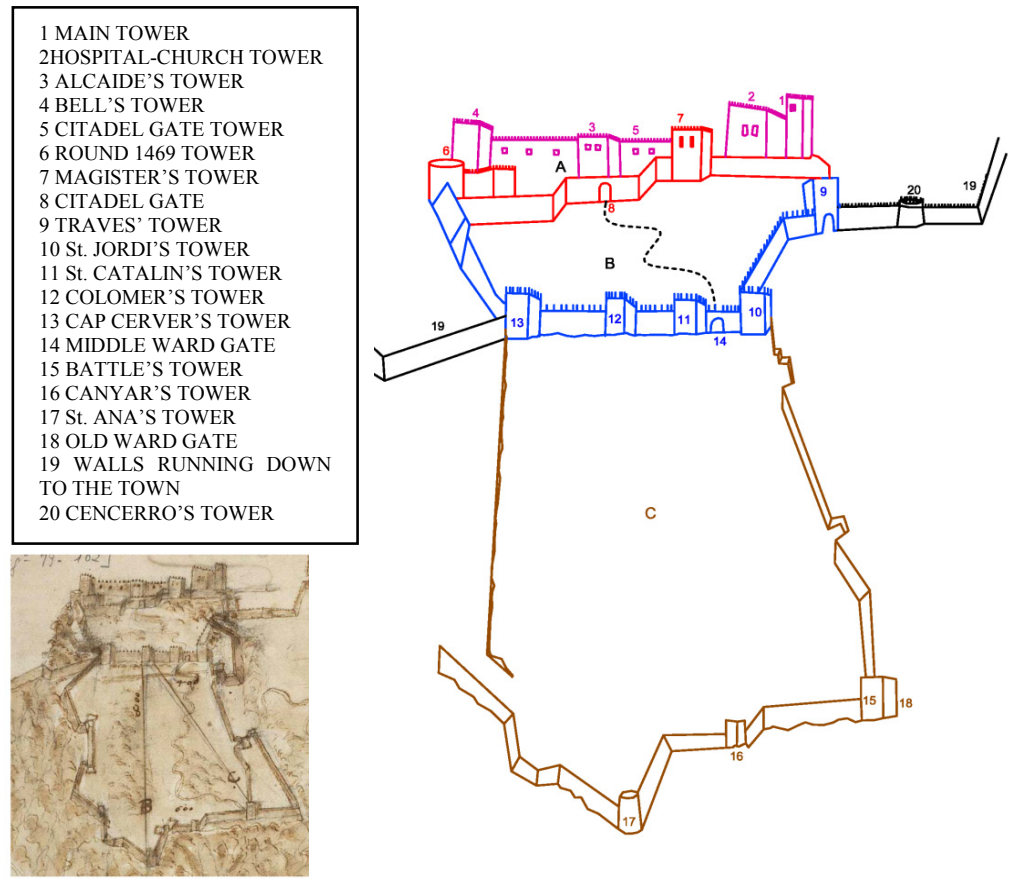

Figure 2: Interpretation of a perspective drawing by Vespasiano Gonzaga dated 1575: AGS. M, P and D. XIX-4, GA Leg. 79-102 (source: authors).

archival documentation of José Hinojosa) (Figure 2, points 6, 7 and 8 of the legend).

Later perspective drawings were also studied, such as one dated to the beginning of the War of the Spanish Succession and held in the British Library [9]. This depicts nearly all the mediaeval towers, indicating that the fortress and especially its citadel retained a mediaeval appearance at this time, with towers and crenellated walls.

The results of this research were used to draw up plans such as the one shown in Figure 3, which depicts a hypothetical reconstruction of the fortress and indicates in the legend the age of the walls and the names thus far identified of the buildings.

Figure 3 shows a hypothetical layout of the fortress prior to Renaissance alterations, and depicts the mediaeval structure of the citadel and its towers, as well as the Muslim towers of the middle ward and the line of the old ward. Thanks to a French plan dated to the early 18th century [10], the most important constructions built in the 15th century can be identified: a double barrier with ditches between the middle ward and the citadel, and a new gate in the northern part protected by two new walls (built in 1474). From the city, the fortress was entered through the Sant Jordi and Través towers located in the upper esplanade. The city also gave direct access to the northern section of the citadel ditch. 


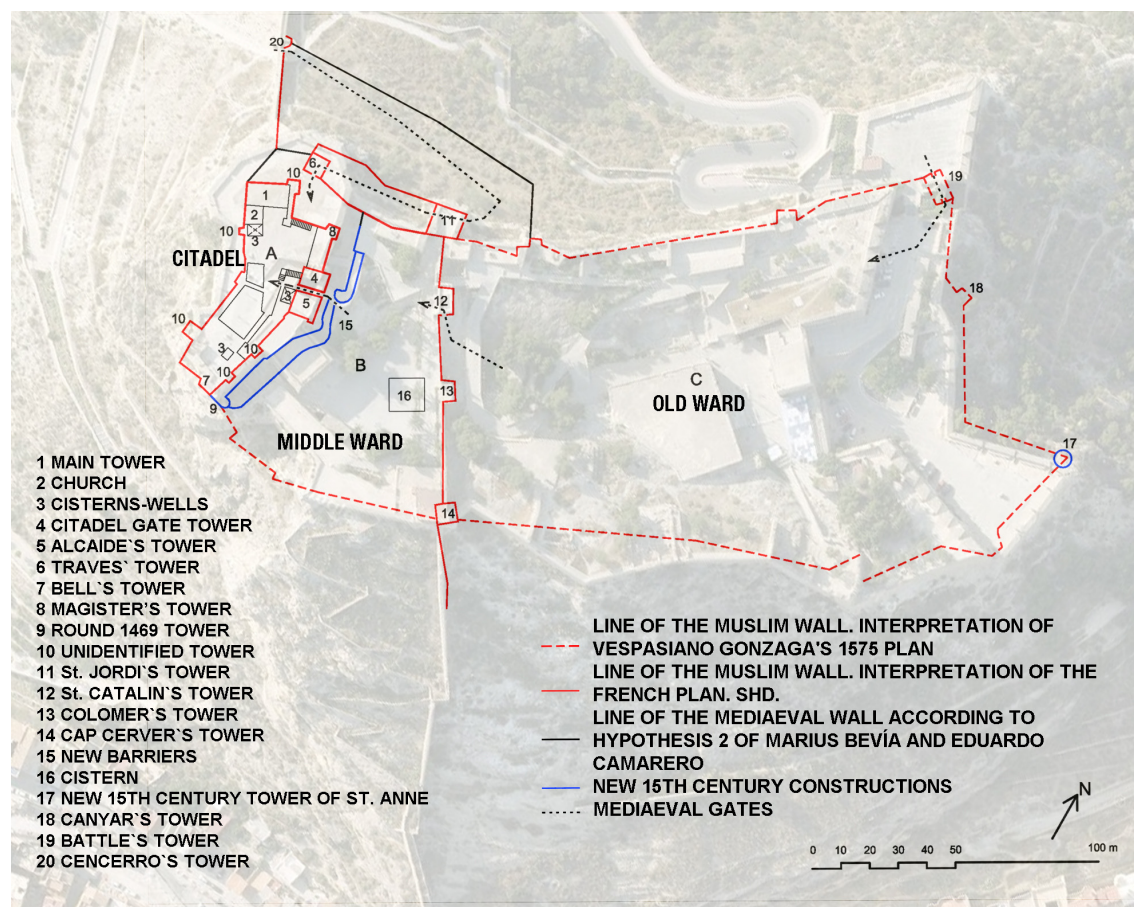

Figure 3: Hypothesis on the status of the castle buildings in the Christian era, superimposed onto a contemporary photograph (source: authors).

External access to the town was identified from the old ward through the Batalla Tower, as was internal access from the old ward through the Santa Catalina Tower. Likewise, the location of the three citadel cisterns and one middle ward cistern was identified, as well as the site and dimensions of the Homenaje tower and the Chapel.

\subsection{6th century: the fortress bastions}

The 16th century was characterised by the emergence and consolidation of bastions in response to the evolution of weapons and offensive strategies against fortresses. To study the fortress in the 16th century, treatises on fortification and artillery by various authors were consulted.

During the reign of Charles V, Alicante was one of most important ports and fortresses in the Mediterranean. The city was reinforced with a modern walled enclosure with circular towers capable of accommodating the artillery.

An anonymous report held in the Municipal Archives of Alicante [11] and dating to the time of Charles $\mathrm{V}$ records proposals for some important projects: closing the Travesa gate, and consequently opening a new gate in the west wall of the esplanade, the construction of an escarpment around the Muslim wall of the middle ward and its towers, the construction of a base around the Sant Jordi 
tower, enlargement of the square next to the new gate, etc. The works described in this report were subsequently executed by the Duke of Maqueda. However, the truly important alterations to the Alicante fortress would not be carried out under Charles V, but under his successor Philip II. This was unquestionably the castle's most important period of modernisation, since it marked the start of modernisation of the defensive structures, especially on the northeastern side which was unprotected and vulnerable to attack from the sea through the Arraval Roig area. Philip II ordered modernisation of the defensive structures, and employed two experts in the field of fortification, Fratín and Gonzaga, who had already intervened in the Citadel of Pamplona, with bitter disagreements.

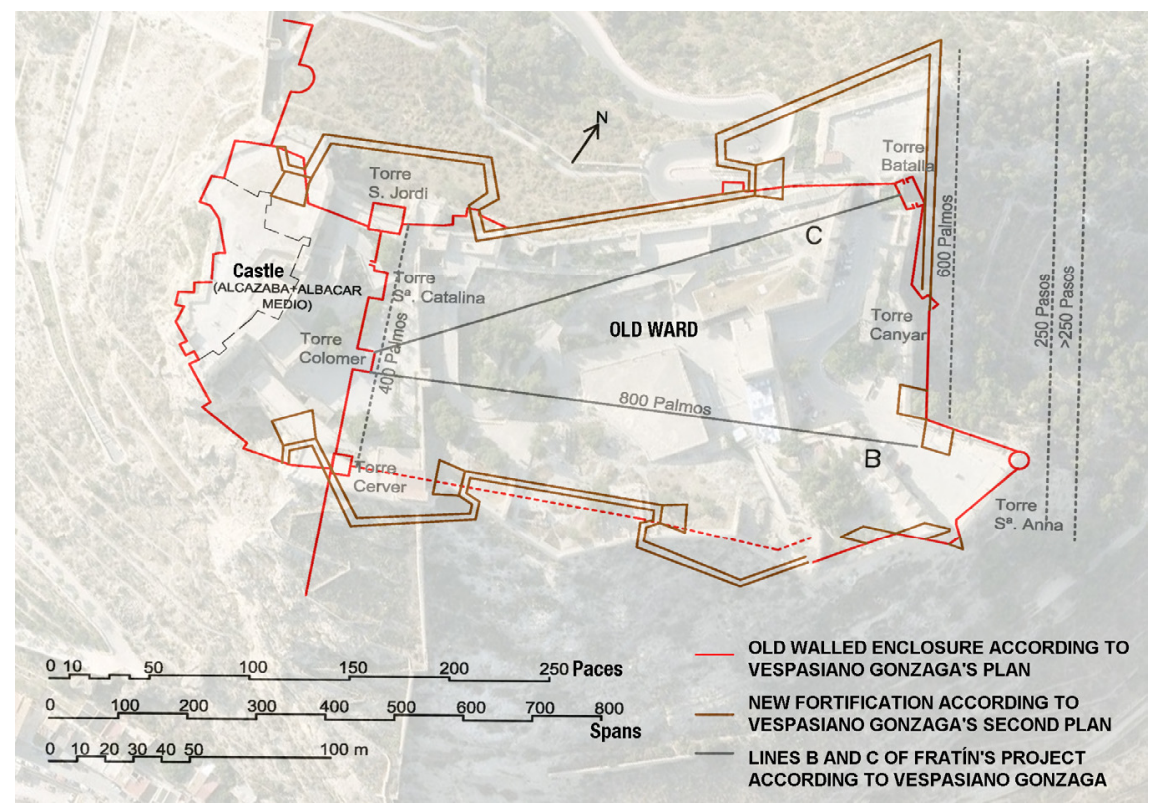

Figure 4: Interpretation of Vespasiano Gonzaga's 1575 plan (AGS. M, P and D. XIX-4, GA Leg. 79-102) superimposed onto a contemporary photograph of the castle (source: authors).

Although documents concerning Fratín's proposal have not survived, Vespasiano Gonzaga's project and correspondence from this period have been preserved.

An analysis of archive documents suggests the following conclusions about this intervention [12] (Figure 4):

- Fratín proposed reducing the size of the castle to reduce garrison costs, taking the lines of defence to points $\mathrm{B}$ and $\mathrm{C}$ of the plan.

- In contrast, Vespasiano Gonzaga criticised Fratín harshly, saying: "it seems impossible to me that a man could propose such an idea". Gonzaga's proposal was to extend the fortress defences out to the edge of the precipice, providing perfect protection for the northeast side of 
the castle and preventing an enemy force from occupying the emplacement outside the walls left by Fratín.

- King Philip II decided to carry out the works proposed by Fratín, moving the line back from the precipice. As can be seen in the photograph, the location of the middle bastions which were built according to Fratín's proposal coincides with the points B and C shown in Gonzaga's plan.

Thus, the fortress appeared as shown in Figure 5, while the rest of the site maintained its mediaeval structure. Fratín's proposal is shown in white, indicating the area left in front of the defensive lines that Gonzaga criticised so harshly.

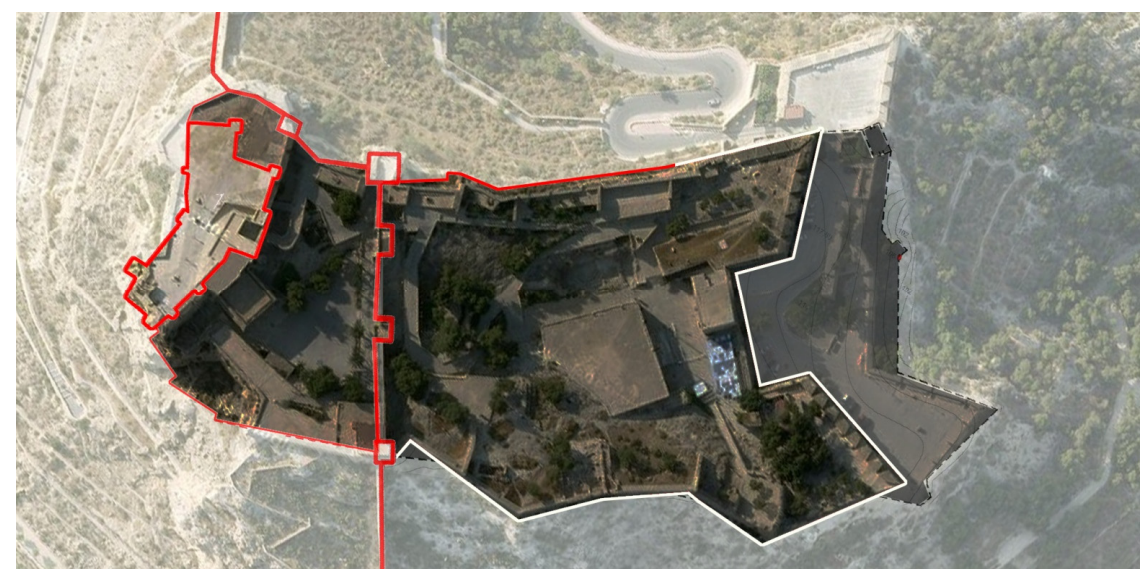

Figure 5: Layout of the castle in the 16th century, following the alterations proposed and carried out by Fratín.

\subsection{7th century: a century of inactivity for the fortress}

Very little work was carried out on the castle and city of Alicante in the 17th century, and the importance of Alicante as a fortress declined in the strategic framework of national defence. Conflicts with France were fought on the French-Spanish border, and in addition, Spain possessed one of the most powerful fleets of the time; consequently, economic and military resources were mainly directed to border cities. However, in the last quarter of the century, concern grew for the city's defence and it became clear that Alicante required further fortification that would prevent troops from landing on the beach of Babel, as proposed by Borzano, Castellón and Valero.

The 1691 French bombardment of Alicante revealed the vulnerability of the castle and city to the growing power of the French navy, underlining the need to fortify and defend both.

Over the course of two days, Alicante received 2,500 bombs, and of its 3,500 homes, only 200 were left standing. 
It was probably in this century that the castle bastion looking towards the sea was built. No written documentation about these alterations has survived, but they are depicted in plans of the time, such as the earlier plan drawn up by Castellón and Valero which shows an ambitious city fortification project that would incorporate the outlying settlements (1688) [13].

\subsection{8th century: the War of the Spanish Succession}

The War of the Spanish Succession was undoubtedly the most important event that the castle witnessed throughout its entire history. During the war, the castle passed through two stages: a period under English command followed by a period under French rule.

After the English had taken the castle in 1706, they altered its defensive structures, mainly strengthening defence of the castle's northeast face. Although no plans were found of the work carried out by the English, it is reflected in later plans such as the French plan of 1710 preserved in the Service Historique de la Défense (SHD) cited above. The English alterations can be summarised as follows:

- They began to modernise the structure of the exterior walls around the upper esplanade (the "Macho"), building batteries large enough to accommodate the new artillery.

- They built bomb-proof vaulted chambers in the old ward to provide shelter for the entire garrison, since those already in existence were too small to offer protection for everyone. The English also built a hospital with bomb-proof vaulted chambers on the north side of the esplanade. In order to store more water, they built a new cistern in the old ward, beside the walls dating to 1575 .

- However, the most important works carried out were in front of the 16th century tenaille built over the earlier Muslim walls: an outwork and a ravelin or low bulwark were constructed, constituting the castle's fourth fortified enclosure. The defence was advanced to the line beside the precipice, as had been proposed 133 years earlier by Gonzaga.

Figure 6 depicts the status of the castle following alterations by the English.

The English held the castle for approximately two and a half years, and it was in late 1708 that Santa Barbara Castle attained its maximum military splendour. The French general, D'Asfeld, had taken the city and proposed to lay siege to the castle. However, this was not an easy task, because it was one of the most impregnable fortresses of the time. Therefore, he proposed a project to construct and blow up a mine beneath it.

Plans conserved in various foreign archives provide information on the physical details of the mine that D'Asfeld devised (Figure 7). He was undoubtedly well-versed on Vauban's treatises, and constructed a mine based on this latter's techniques [14]. 


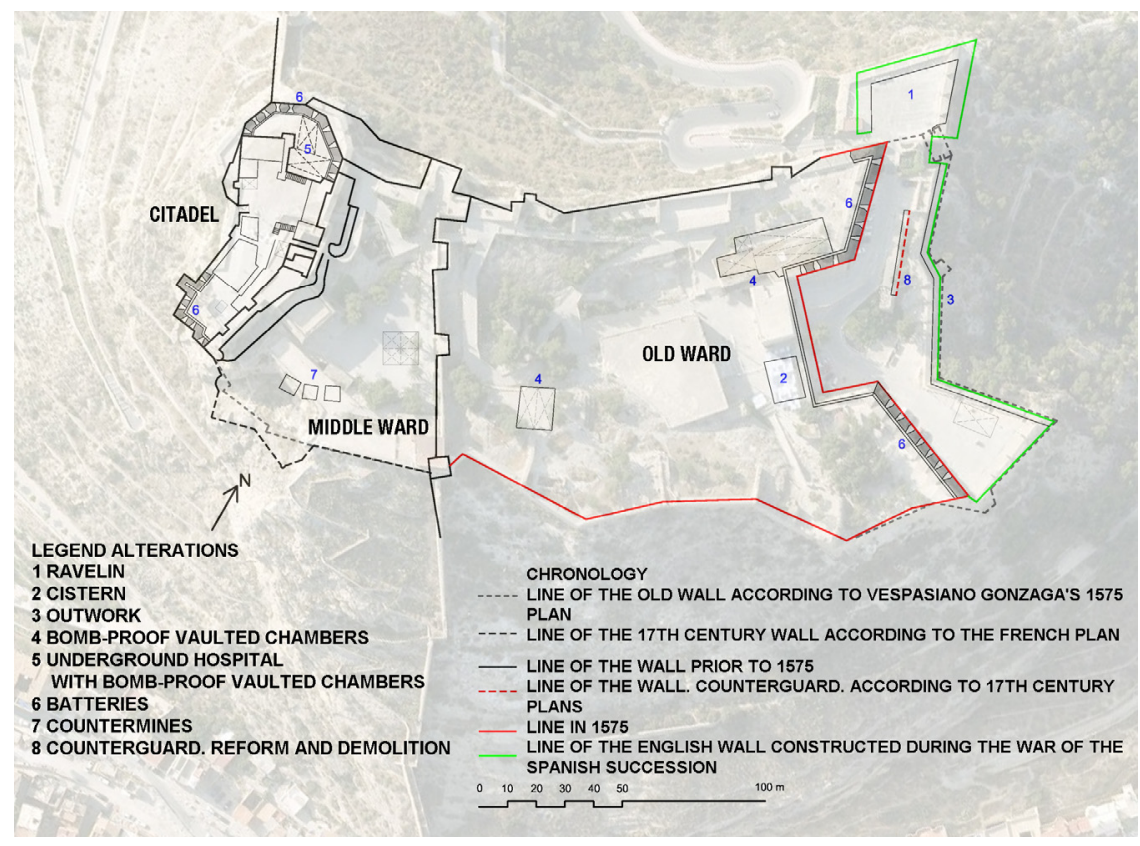

Figure 6: Hypothesis on the status of the castle following alterations by the English.

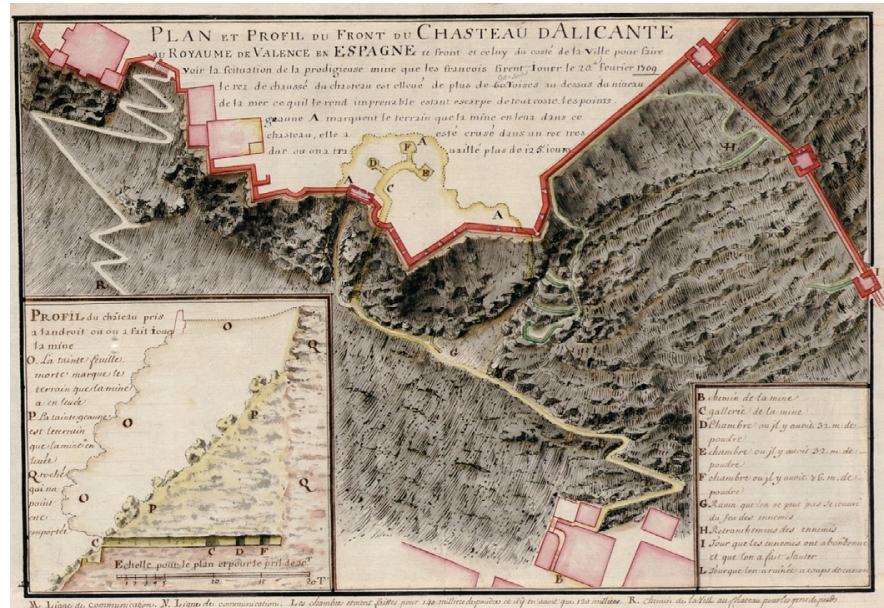

Figure 7: Detail of the mine according to D'Asfeld's plan. SHD. Château de Vincennes. Bibliothèque. In Folio 131e. Feuille 58.

His main objective was to destroy the cistern in the ward, and the central area of the fortress. He constructed three vaulted chambers to achieve the desired effect. Meanwhile, from above and from the trenches that they were building on 
the hillside, the English bombed his men and, under the orders of the English engineer Pagez, built three vertical shafts as a countermine to mitigate the effect of the explosion.

On the 3 March 1709, D'Asfeld blew the mine up, as shown in the picture above, drawn at the time of the explosion. Richards and more than 50 men were killed, but the explosion did not improve the conditions for assault. However, it did damage the cistern, creating a water shortage.

The English endured another month and a half after the explosion, until surrendering the castle on 18 April 1709. D'Asfeld's mine was described at the time as "a prodigious mine which had destroyed half the mount and part of the castle". It was one of the most dramatic events in the castle and city's history, and one of the longest sieges of a fortress in the War of the Spanish Succession.

Its physical effect on the castle can still be seen today. As the contemporary photograph shows, the mine destroyed much of the rock on which the castle stood, and completely razed the bulwark under which it had been constructed.

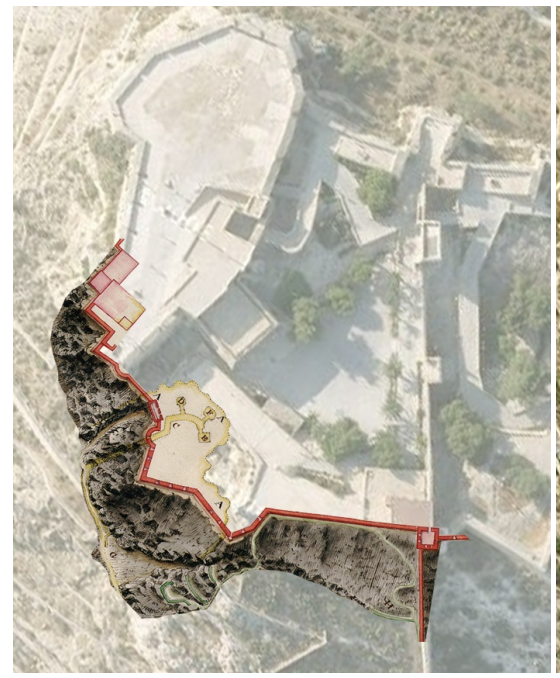

(a)

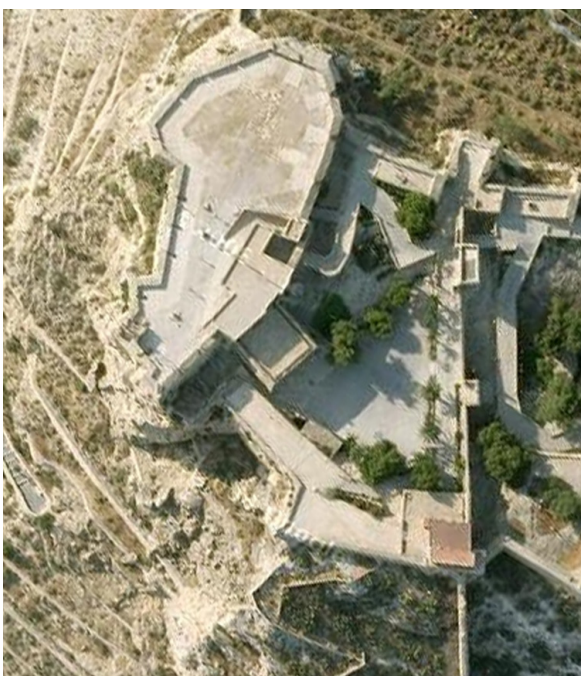

(b)

Figure 8: (a) A photomontage of the historical plan in Figure 7, indicating the site of the mine superimposed onto a contemporary photograph of the castle. (b) An aerial photograph of the castle shows the effects of the mine on the bulwark that looked out to sea.

\section{Conclusions}

The episode of the mine left the fortress completely defenceless on the western side of Mount Benacantil. Nevertheless, the castle's main problem was its height, standing at 140 metres above sea level. This made it impossible to mount an enfilade against approaching ships due to the steep angle of the line of fire. 
Consequently, various projects to fortify this slope were proposed in the 18th century by Antonio Montaigut (1924), Esteban de Panon (1750) and Zermeño (1751).

The last decades of the 18th century were marked by a period of economic austerity, and although numerous projects for work on the castle were proposed, the majority were not carried out.

Due to the threat posed by the Peninsular War, with the possibility of attack on the city by land, and the vulnerable state of the city walls, proposals were made to construct a new walled enclosure and fortify some of the nearby imposing hills. Such was the case of the San Fernando Fort on Mount Tossal, which overlooked the port and the city, and was constructed to overcome the limitations of Santa Barbara Castle in this respect.

The castle became obsolete as rifled artillery advanced, but was nevertheless considered capable of withstanding a prolonged siege and necessary for relief: the last stronghold.

Today, it remains as an attractive architectural monument from which to enjoy views of the docks and city, and has become a cultural point of reference in Alicante due to its exhibition halls.

\section{References}

[1] Pérez Millán, M.I. (2011). Historia del Castillo de Santa Bárbara de Alicante desde sus orígenes hasta la Guerra de la Independencia. Unpublished thesis, University of Alicante "only available in Spanish".

[2] González Avilés, A.B. (2012). Génesis y evolución de las fortificaciones abaluartadas de Alicante (siglos XVI-XVIII). Unpublished thesis, University of Alicante "only available in Spanish".

[3] Figueras Pacheco, F. (1962). El Castillo de Santa Bárbara de Alicante. Publicaciones de la Comisión de Cultura del Excmo. Ayuntamiento de Alicante, Alicante "only available in Spanish".

[4] Rosser Limiñana, P. (1990). Origen y evolución de las Murallas de Alicante. Ayuntamiento de Alicante. Conselleria de Cultura, educación i Ciencia. Generalitat Valenciana, Alicante "only available in Spanish".

[5] Hinojosa Montalvo, J. (1990). La clau del Regne. Patronato Municial del Centenario de la ciudad de Alicante, Alicante.

[6] Martínez Morellá, V. (1953). Cartas al rey Don Martin, El Humano, a Alicante, Alicante "only available in Spanish".

[7] Beviá, M., Camarero, E. (1991). "Propuesta para la reconstrucción morfológica de la alcazaba de Alicante: estructura anterior a las transformaciones renacentistas" en Azuar Ruiz, R. (comp). Fortificaciones y Castillo de Alicante. Caja de Ahorros Provincial de Alicante, Alicante pp. 215-234 "only available in Spanish".

[8] Rosser Limiñana, P. (1991). "Excavación arqueológica de urgencia en el Macho del Castillo de Santa Bárbara (Alicante)", en Azuar Ruiz, R. (comp). Fortificaciones y Castillo de Alicante. Caja de Ahorros Provincial de Alicante, Alicante, pp. 183-212, “only available in Spanish". 
[9] BL. Maps K Top 73 67. 1703-1708.

[10] Service Historique de la Défense (SHD). Château de Vincennes. Bibliothèque. In Folio 131e, Feuille 56.

[11] AMA. Visita del S. or D.n Genronimo Arrufat oidor de la Real Audiencia y Real Comisario en virtud de Orden de S.M. Año 1553. Arm 2. Lib 53.

[12] Pérez Millán, M.I. (2014). "Las intervenciones de los ingenieros italianos en la fortificación alicantina durante la segunda mitad del siglo XVI", in Biblio $3 W$. Revista Bibliográfica de Geografía y Ciencias Sociales, [online]. Barcelona: Universidad de Barcelona, 15 de agosto de 2014, Vol. XIX, no 1086 http://www.ub.es/geocrit/b3w-1086.htm "only available in Spanish".

[13] SGE. $\mathrm{CH}$ n $^{\circ} 287$.

[14] Echarri Iribarren, V. (2014). "El sitio de Alicante y la mina que hicieron las tropas hispano-francesas bajo el castillo en 1708-1709: une des plus fortes que jamais ait été faitte", in Tiempos Modernos, vol. 8, $\mathrm{n}^{\mathrm{o}} 28$, “only available in Spanish". 